\title{
Influencing Factors of Learning Experience in Online Large-Class Teaching Semantic Analysis Based on Students' Classroom Feedback Language Materials
}

\author{
Qing Liu \\ School of Education Science, Guangxi College of Education, Nanning, Guangxi, China
}

\begin{abstract}
As the learners' perception and reaction in multiple aspects during the course learning, learning experience is of great importance for the study of educational evaluation and the optimization of teacher teaching and teaching management. According to the text semantic analysis and questionnaire survey on students' learning feedback in online large classes, the NLPIR-Parser big-data semantic intelligent analysis platform is used in this paper to carry on keywords extraction and analysis, text sentiment analysis, text clustering and abstract extraction after the processing of original corpus, and then SPSS22.0 software is used to conduct Pearson correlation analysis on the score of text sentiment and the statistical data of questionnaire survey. The results show that the results of text semantic analysis and questionnaire survey have the consistency in positive learning experience; students' negative emotional experience has a significantly reverse correlation with learning effect score; teacher teaching, student learning, course characteristics and learning environment are proved to be the main influencing factors of students' learning experience, in which, teacher teaching plays a leading role. Then, the specific thinking of improving students' learning experience is put forward on the basis of research results.
\end{abstract}

Keywords: learning experience, classroom feedback, language materials, semantic analysis, NLPIR-Parser, large class teaching, online teaching

\section{Introduction}

Large class teaching is an organizational form of teaching with a large number of students in a single teaching class $^{[1]}$, e-learning is an information technology supported teaching mode in cyberspace ${ }^{[2]}$. The unavoidably participation in online teaching or management practice of all stakeholders in educational field driven by the outbreak of COVID-19 at the beginning of 2020 has pushed e-Learning to be focused by all circles of life, which will continuously affect the educational development until the post epidemic era ${ }^{[3-4]}$. As one of the new teaching organization forms of "organizational system-based e-learning" ${ }^{[3]}$, online large-class teaching is to take the class as unit to implement the whole-staff and whole-process online teaching by combining the original large class teaching management structure and system with network teaching situation. It has not only the characteristics of in-class teaching, such as classroom organization, teaching plan, management standardization and teaching-learning synchronicity, but also the features brought by information technology, such as various teaching mode, convenient information acquisition, timely teaching feedback, frequent teacher-student interaction, open teaching environment, the dependence on network condition and equipment, etc.

As one of the important indexes reflecting teaching quality, learning experience refers to the learners' perception and reaction on course contents and teaching activities in multiple aspects during the course learning ${ }^{[5]}$. Teachers, educational managers and researchers all concern about the learning experience of students in large-class online teaching and its influencing factors. The difficulties either in the acquisition of objective data reflecting students' feelings from traditional questionnaires and interviews ${ }^{[6]}$ or in the accurate identification of students' mentality by structured data from routine teaching examination ${ }^{[7]}$ have pushed researchers to pay more attention to the analysis of learning experience texts such as summary, induction and evaluation of learners' expressing their learning ISSN: 0010-8189

C CONVERTER 2020

www.converter-magazine.info 
feelings ${ }^{[5]}$. Therefore, in this paper, semantic analysis is conducted on students' learning feedback texts from online large-class teaching as the original corpus, so as to deeply explore the characteristics of students' learning experience and its main influencing factors, and puts forward measures to improve students' learning experience, in the hope of providing reference for the research and practice of class system-based online and offline teaching and management.

\section{Research Status}

After the cross-database searching in CNKI database (April 2021) with "learning experience" as the theme, "text analysis" or "semantic analysis" and "sentiment analysis" as the article abstract, at most 21 Chinese documents are obtained, in which only 3 documents issued after 2020 have high correlation. Jia Wenjun (2020) et al. believe that with the significant impact of external hardware devices, school support services, platform operation, teaching conditions, students' learning status, schoolwork tasks, online learning willingness, etc. on college students' online learning experience, the research on learning experience will be an important field in the future education ${ }^{[8]}$; Li Hui (2021) believes that sentiment plays a key role in the non intelligence factors influencing learners' psychology and behavior ${ }^{[5]}$, whose data are mainly from texts; Xu Lai (2021) et al. believe that network technology and environment, learning resources, teaching interaction, students' learning adaptability, teachers' curriculum management can mainly reflect students' negative experience, in which network technology and environment are the most prominent, while teachers' teaching methods and efforts are the main sources of positive experience ${ }^{[9]}$.

The abundant research achievements of domestic and foreign scholars in the field of text analysis technology and application, sentiment analysis on teaching evaluation text, etc. have provided theoretical and technical supports for the research of learning experience based on text semantic analysis. Ekman's (1993) theory that the six basic emotions of people are happiness, anger, sadness, fear, disgust and surprise has been the important theoretical basis for text semantic analysis ${ }^{[10]}$; based on which, the addition of the "like" category into the "Chinese sentiment-vocabulary ontology database" of Dalian University of Technology has made positive sentiment divided more specifically ${ }^{[5]}$; Huang Xiaobin and Zhao Chao (2009) believe that the main technologies of text mining include: feature extraction, text classification, text clustering, association analysis, text summary and trend prediction $^{[11]}$; Wei Wei (2011) et al. believe that with the ability of text semantic analysis to detect and mine the opinions, preferences, emotions, etc. contained in subjective texts, the judgement on sentimental polarity of words should be combined with the specific context and field as well as the choice of appropriate granularity ${ }^{[12]}$; Xi Xuefeng and Zhou Guodong (2016) believe that human natural language is characterized by recursiveness, with its processing having good preliminary application effect in part-of-speech tagging, word meaning learning, sentiment analysis and so on ${ }^{[13]}$; the NLPIR-Parser big-data semantic intelligent analysis platform(hereinafter referred to as NLPIR-Parser) developed by Zhang Huaping for 20 years can integrate network data collection, natural language processing, text mining, text retrieval and other technologies and functions, which has been verified by multiple institutions ${ }^{[14]}$.

Chinese scholars's text semantic analysis on students' teaching evaluation texts has been started from the Encoding / Decoding in College Students' Teaching Evaluation ${ }^{[15]}$ published by Mei Shiwei and Ding Honghao in 2008, and the recent researches mainly focus on the sentiment analysis and clustering analysis of teaching evaluation texts to explore the factors influencing the teaching quality and the focus of students' attention.Based on HowNet emotional lexicon, Luo Yuping (2018) et al. studied the sentimental polarity analysis methods of students' comments on teaching by using semantic analysis techniques ${ }^{[16]}$; the statistical analysis and text mining on students' teaching evaluation data conducted by He Xijun and Zhu Xiangyu (2019) show that students' attentions are paid to teachers' teaching attitude, teaching methods, class interaction and course content logicality during class learning ${ }^{[17]}$; according to the analysis on students' teaching evaluation texts, Wang Jun and Wang Caixia (2020) found that recognition attitude, course content, teaching method, achievement of educational objectives, and scientificity of curriculum design and management are the main factors affecting the teaching quality of general

ISSN: 0010-8189

(C) CONVERTER 2020

www.converter-magazine.info 
education in colleges and universities ${ }^{[18]}$; Chen Yuchan and Liu Wei (2020) proposed and conducted effectiveness verification on a research method of opinion extraction and clustering of student evaluation texts ${ }^{[19]}$. Among the foreign scholars, Cabedo (2016) et al. used clustering analysis on MOOC Knowledge project data to carry on the identification and description of of online learners' learning experience by K-Means and SOM algorithms ${ }^{[20]}$, Colace (2014) and Ortigosa (2014) et al. believed that with the positive, negative, or neutral sentiment orientations as the main focus of text sentiment analysis in education field, there are few researches on sentiment classification of joy, anger and sadness ${ }^{[21-22]}$, thus learners' sentiment analysis model with the ability of realizing multi-level sentiment classification for learning experience text is proposed by $\mathrm{Li} \mathrm{Hui}^{[5]}$.

In conclusion, with the possibility of both class feedback text and teaching evaluation text in online large-class teaching belonging to the learning experience texts, the gradually mature technologies of sentiment polarity analysis and clustering analysis in text semantic analysis have been widely used and verified in the researches of learning experience, and the full-category sentiment analysis and multi-dimensional text mining have also been actively explored by researchers, thus laying the foundation for the exploration on the factors influencing learning experience in online large-class teaching from the two basic dimensions of teachers' teaching and students' learning on the basis of keyword, sentiment polarity and clustering analysis of classroom feedback texts.

\section{Data Sources and Research Method}

\subsection{Data sources}

As an online interactive tool in college classroom with the ability of conveniently linking online and offline classroom teaching ${ }^{[23]}$, Micro-TA is used to set the module of "class feedback", so as to acquire the basic data by issuing class feedback questionnaires during the online large-class teaching in a non mandatory and anonymous way. The questionnaire based on the comprehensive two-dimensional scale (Table 1) is filled by students to conduct overall rating on teachers'class teaching, and the comment function opened in questionnaire allows students to publish their own learning experience evaluation.

The questionnaires are distributed to 304 students in 6 online large classes taking three different curricula taught by the same teacher in a college, in which, class 1 and class 4 have the same curriculum. There are 240 students participated in submitting classroom feedback questionnaire scores and sending learning experience evaluation texts, accounting for $78.9 \%$, and 240 pieces of original corpus including 5,636 characters are collected.

Table 1 Class Feedback Questionnaire Evaluation Scale

\begin{tabular}{|c|c|c|}
\hline $\begin{array}{c}\text { Dimension } \\
\text { name }\end{array}$ & $\begin{array}{c}\text { Weigh } \\
t\end{array}$ & Description \\
\hline $\begin{array}{l}\text { Teachers } \\
\text { teaching }\end{array}$ & $50 \%$ & $\begin{array}{l}\text { Whether teachers have made full preparation for } \\
\text { teaching, with clear teaching objectives, } \\
\text { prominent key and difficult points, } \\
\text { conscientious, resposible and patient teaching } \\
\text { attitude or not. } \\
5 \text { points: Very good; } 4 \text { points: Good; } 3 \text { points: } \\
\text { Common; } 2 \text { points: Poor; } 1 \text { point: Very Poor; }\end{array}$ \\
\hline $\begin{array}{l}\text { Learning } \\
\text { effect }\end{array}$ & $50 \%$ & $\begin{array}{l}5 \text { points: Fully understand the teaching content; } \\
4 \text { points: Only few difficult points can not be } \\
\text { understood; } \\
3 \text { points: Basically understand the teaching } \\
\text { content; } \\
2 \text { points: Only few contents can be understood; } \\
1 \text { point: Totally do not understand; }\end{array}$ \\
\hline
\end{tabular}

3.2 Research methods

ISSN: 0010-8189

(c) CONVERTER 2020 
Combining questionnaire survey and text semantic analysis, this research is first to acquire the questionnaire score data of each class and preprocess the evaluation text data; second, the evaluation texts are conducted with new word extraction, keyword extraction and word frequency statistics, language statistics based on word segmentation results and "stop list of Harbin Institute of Technology", text clustering, entity extraction and sentimental polarity analysis by using the function of NLPIR-Parser, thereby exploring the features of students' learning experience and its related influencing factors; third, according to the results of text semantic analysis and questionnaire score statistics, the statistical data of emotional value score and questionnaire score of text sentimental analysis of each class are conducted with Pearson correlation analysis by using SPSS22.0, so as to further explore the connotation of different research data.

\subsection{Text data preprocessing}

The preprocessing of students' evaluation text data can improve the accuracy of analysis by effectively reducing the impact of indiscernible information, low-value information and synonymous information on text semantic analysis results, which is conducted as follows: (1)Translate a small amount of English into Chinese; (2)remove a few emoticons and special symbols; (3)unify and classify the words with similar meanings; (4)edit custom dictionary according to the characteristics of e-learning and college students; (5)add new stop words into the "stop list of Harbin Institute of Technology" according to the preliminary word segmentation result. 5,597characters of corpus are obtained after the first three steps.

\section{Results}

\subsection{Keyword extraction and analysis}

The keyword extraction by NLPIR-Parser after corpus preprocessing and new word extraction helps us to obtain the words, part of speech, weight and word frequency of 407 keywords, including 132 nouns, 194 verbs and 36 adjectives, accounting for $88.95 \%$ of the total number of keywords, in which, there is a significant correlation between the weight and word frequency of keywords at the confidence level (double test) of 0.01 , with their Pearson correlation coefficient of 0.871 . The weight and word frequency of keyword with the ability of reflecting the key points of students' attention in class learning ${ }^{[18]}$ allow us to infer the main influencing factors of students' learning experience from keyword semantics. The ability of adjectives to relatively and accurately express students' intuitive feelings is beneficial to judge the overall sentimental tendency of their learning experience.

The word frequency of keywords with the weight ranked first 50 is 681 (Table 2), which can be classified into 7 categories (Table 3) according to the meaning of different keywords and the comparison with original text. There are 17 adjectives (Fig. 1) with the word frequency of exceeding 3, in which 13 words with positive meaning account for $76.47 \%$, such as "teachers' hard work", "teachers' serious lecture", "the very interesting content", "tension, stimulation and happiness", etc., which shows that the superiority of students' positive learning experience and its various sources. The binary word pairs obtained from the comparison with original text and language statistics show that the adjectives of positive meaning are mainly related to teachers' teaching attitude, teaching status and teaching methods, while the adjectives of negative meaning are mainly related to teachers' teaching methods, learning gains and network conditions (Table 4).

Table 2 Keywords with weight ranked first 50

\begin{tabular}{cccccccc}
\hline $\begin{array}{c}\text { Serial } \\
\text { numb } \\
\text { er }\end{array}$ & Words & Weight & $\begin{array}{c}\text { Word } \\
\text { frequency }\end{array}$ & $\begin{array}{c}\text { Serial } \\
\text { numb } \\
\text { er }\end{array}$ & Words & Weight & $\begin{array}{c}\text { Word } \\
\text { frequency }\end{array}$ \\
\hline 1 & Teacher & 31.99 & 81 & 26 & Time & 8.65 & 8
\end{tabular}

ISSN: 0010-8189 


\begin{tabular}{|c|c|c|c|c|c|c|c|}
\hline 2 & $\begin{array}{l}\text { Attending } \\
\text { class }\end{array}$ & 24.80 & 45 & 27 & Still have & 8.47 & 6 \\
\hline 3 & $\begin{array}{l}\text { Teaching } \\
\text { class }\end{array}$ & 21.39 & 31 & 28 & Data & 8.47 & 6 \\
\hline 4 & Allow & 20.54 & 29 & 29 & $\begin{array}{l}\text { Preemptive } \\
\text { answer }\end{array}$ & 8.47 & 6 \\
\hline 5 & Content & 18.61 & 34 & 30 & $\begin{array}{l}\text { Thanks for } \\
\text { teacher }\end{array}$ & 7.49 & 6 \\
\hline 6 & Class & 15.34 & 19 & 31 & $\begin{array}{l}\text { Being able } \\
\text { to }\end{array}$ & 7.48 & 6 \\
\hline 7 & Classmate & 14.21 & 22 & 32 & Explanation & 7.47 & 12 \\
\hline 8 & $\begin{array}{l}\text { Knowledg } \\
\mathrm{e}\end{array}$ & 13.06 & 20 & 33 & Answering & 7.44 & 7 \\
\hline 9 & Sensation & 12.67 & 18 & 34 & Subject & 7.44 & 7 \\
\hline 10 & Question & 11.75 & 21 & 35 & $\begin{array}{l}\text { Comprehen } \\
\mathrm{d}\end{array}$ & 7.38 & 5 \\
\hline 11 & Possible & 10.59 & 9 & 36 & $\begin{array}{l}\text { Lesson } \\
\text { preview }\end{array}$ & 7.38 & 5 \\
\hline 12 & Learning & 10.53 & 8 & 37 & Class & 6.71 & 40 \\
\hline 13 & $\begin{array}{l}\text { Interactio } \\
\mathrm{n}\end{array}$ & 10.39 & 11 & 38 & Teaching & 6.58 & 7 \\
\hline 14 & $\begin{array}{l}\text { Understan } \\
\mathrm{d}\end{array}$ & 10.3 & 14 & 39 & Speed & 6.50 & 6 \\
\hline 15 & Method & 10.28 & 16 & 40 & Do not have & 6.49 & 16 \\
\hline 16 & $\begin{array}{l}\text { Answerin } \\
\mathrm{g} \text { question }\end{array}$ & 10.16 & 6 & 41 & Solution & 6.36 & 5 \\
\hline 17 & Like & 9.64 & 10 & 42 & Rest & 6.31 & 6 \\
\hline 18 & Student & 9.62 & 9 & 43 & Situation & 6.22 & 4 \\
\hline 19 & Notes & 9.53 & 10 & 44 & Sound & 6.22 & 4 \\
\hline 20 & Network & 9.51 & 7 & 45 & Progress & 6.22 & 4 \\
\hline 21 & Effect & 9.45 & 8 & 46 & $\begin{array}{l}\text { Live } \\
\text { broadcastin } \\
\mathrm{g}\end{array}$ & 6.22 & 4 \\
\hline 22 & $\begin{array}{l}\text { Teachers } \\
\text { teaching }\end{array}$ & 9.41 & 23 & 47 & A little & 5.95 & 3 \\
\hline 23 & Think & 9.33 & 21 & 48 & $\begin{array}{l}\text { Hope the } \\
\text { teacher }\end{array}$ & 5.95 & 3 \\
\hline 24 & $\begin{array}{l}\text { Screen } \\
\text { capture }\end{array}$ & 8.85 & 7 & 49 & $\begin{array}{l}\text { Turn off the } \\
\text { microphone }\end{array}$ & 5.95 & 3 \\
\hline 25 & One time & 8.80 & 8 & 50 & Comparison & 5.78 & 15 \\
\hline Ave & ge weight & 9.97 & $\begin{array}{l}\text { Total word } \\
\text { frequency }\end{array}$ & & 681 & $\begin{array}{l}\text { Average } \\
\text { word } \\
\text { frequency }\end{array}$ & 13.6 \\
\hline
\end{tabular}

Table 3 Classification for keywords with weight ranked first 50

\begin{tabular}{|c|c|c|c|}
\hline Category & $\begin{array}{l}\text { Word } \\
\text { frequency }\end{array}$ & $\begin{array}{l}\text { Proportion } \\
(\%)\end{array}$ & Keyword \\
\hline $\begin{array}{l}\text { Teachers' teaching } \\
\text { attitude and state }\end{array}$ & 102 & 14.98 & $\begin{array}{l}\text { Teacher, student, thanks for teacher, } \\
\text { rest }\end{array}$ \\
\hline $\begin{array}{l}\text { Teachers' } \\
\text { methods }\end{array}$ & 117 & 17.18 & $\begin{array}{l}\text { Teaching class, teachers teaching, } \\
\text { interaction, method, like, explanation, } \\
\text { teaching, screen capture }\end{array}$ \\
\hline Students' learning desire & 80 & 11.75 & $\begin{array}{l}\text { Attend class, classroom, learning, hope } \\
\text { the teacher, lesson preview }\end{array}$ \\
\hline Classroom activities & 56 & 8.22 & $\begin{array}{l}\text { Question, answer the question, notes, } \\
\text { Preemptive answer, speed, answering }\end{array}$ \\
\hline Students' & 144 & 21.15 & Allow, knowledge, effect, think, \\
\hline
\end{tabular}

ISSN: 0010-8189 
learning acquisition

Learning environment

Subtotal

Others

In total sensation, being able to, solution, comparison, understand, comprehend, possible

Content, progress, subject, data, time

Classmate. network, sound, turn off the microphone, live broadcasting

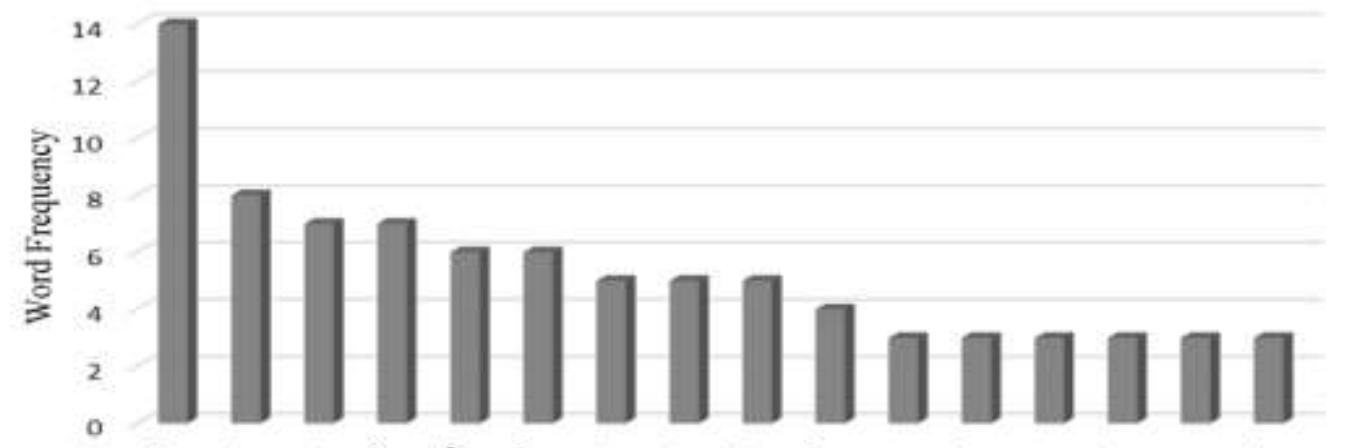

Words

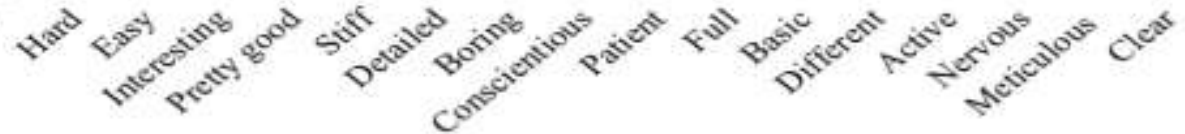

Fig 1: Adjectives with word frequency ranked first 17

Table 4 Binary word pairs of adjectives with high word frequency

\begin{tabular}{|c|c|c|c|c|c|c|c|c|}
\hline $\begin{array}{l}\text { The } \\
\text { previous } \\
\text { word }\end{array}$ & $\begin{array}{l}\text { The latter } \\
\text { word }\end{array}$ & $\begin{array}{c}\text { Co } \\
\text { occur } \\
\text { rence } \\
\text { frequ } \\
\text { ency } \\
\end{array}$ & $\begin{array}{l}\text { The } \\
\text { previou } \\
\text { s word }\end{array}$ & $\begin{array}{l}\text { The } \\
\text { latter } \\
\text { word }\end{array}$ & $\begin{array}{c}\text { Co } \\
\text { occur } \\
\text { rence } \\
\text { frequ } \\
\text { ency } \\
\end{array}$ & $\begin{array}{l}\text { The } \\
\text { previou } \\
\text { s word }\end{array}$ & $\begin{array}{l}\text { The } \\
\text { latter } \\
\text { word }\end{array}$ & $\begin{array}{c}\text { Co } \\
\text { occur } \\
\text { rence } \\
\text { frequ } \\
\text { ency } \\
\end{array}$ \\
\hline \multirow{8}{*}{ Hard } & Teacher & 4 & \multirow{7}{*}{$\begin{array}{l}\text { Interesti } \\
\text { ng }\end{array}$} & Note & 1 & \multirow{6}{*}{ Stiff } & Interrupt & 1 \\
\hline & $\begin{array}{l}\text { Teachers } \\
\text { teaching }\end{array}$ & 1 & & $\begin{array}{l}\text { Classr } \\
\text { oom }\end{array}$ & 1 & & $\begin{array}{l}\text { Not } \\
\text { realy }\end{array}$ & 1 \\
\hline & Attend class & 1 & & $\begin{array}{l}\text { Teach } \\
\text { er }\end{array}$ & 1 & & $\begin{array}{l}\text { Sentatio } \\
\mathrm{n}\end{array}$ & 1 \\
\hline & $\begin{array}{l}\text { Teaching } \\
\text { class }\end{array}$ & 1 & & $\begin{array}{l}\text { Exam } \\
\text { ple }\end{array}$ & 1 & & $\begin{array}{l}\text { Mechani } \\
\text { zation }\end{array}$ & 1 \\
\hline & This time & 1 & & $\begin{array}{l}\text { Preem } \\
\text { ptive } \\
\text { answe } \\
r\end{array}$ & 1 & & Boring & 1 \\
\hline & Content & 1 & & $\begin{array}{l}\text { Pretty } \\
\text { good }\end{array}$ & 1 & & Hate & 1 \\
\hline & Attend class & 1 & & $\begin{array}{l}\text { Have } \\
\text { learne } \\
\text { d }\end{array}$ & 1 & Inactive & \multirow{5}{*}{ Stiff } & 1 \\
\hline & $\begin{array}{l}\text { Hope the } \\
\text { teacher }\end{array}$ & 1 & $\begin{array}{l}\text { more } \\
\text { example } \\
\mathrm{s}\end{array}$ & \multirow{4}{*}{$\begin{array}{c}\text { Interes } \\
\text { ting }\end{array}$} & 1 & Too & & 1 \\
\hline $\begin{array}{l}\text { Class } \\
\text { supervisor }\end{array}$ & \multirow{3}{*}{ Hard } & 1 & Teacher & & 2 & Not that & & 1 \\
\hline Effort & & 1 & Content & & 2 & A little & & 1 \\
\hline Teacher & & 8 & Vivid & & 1 & $\begin{array}{l}\text { Classroo } \\
\mathrm{m}\end{array}$ & & 1 \\
\hline
\end{tabular}

ISSN: 0010-8189

(c) CONVERTER 2020 


\begin{tabular}{lclll}
$\begin{array}{l}\text { Thanks for } \\
\text { teacher }\end{array}$ & 1 & $\begin{array}{l}\text { Questio } \\
\text { n type }\end{array}$ & 1 & $\begin{array}{l}\text { Attend } \\
\text { class }\end{array}$ \\
$\begin{array}{l}\text { Teaching } \\
\text { class is } \\
\text { pretty }\end{array}$ & 1 & & \\
\hline
\end{tabular}

\subsection{Text sentiment analysis}

The results of automatic sentimental polarity analysis and sentimental value measurement ${ }^{[14]}$ by NLPIR-Parser's function of universal sentiment analysis are as follows: The comprehensive sentimental polarity of the six classes is positive, and the total score of comprehensive sentimental value is 293.5 , in which the total score of positive sentimental value is 500.5 and the total score of negative sentimental value is - 207 (Table 5); the mean of comprehensive sentimental scores from class 1 to class 4 is 31.88, which is significantly lower than class 5 and class 6; the results of text sentiment analysis are consistent with the semantic polarity analysis of adjective keywords.

Table 5 Sentiment value score of experience evaluation text of each class

\begin{tabular}{clll}
\hline Class & $\begin{array}{l}\text { Sentiment } \\
\text { score }\end{array}$ & $\begin{array}{l}\text { Positive } \\
\text { score }\end{array}$ & $\begin{array}{l}\text { Negative } \\
\text { score }\end{array}$ \\
\hline Class 1 & 31 & 56 & -25 \\
Class 2 & 25 & 59 & -34 \\
Class 3 & 34 & 45 & -11 \\
Class 4 & 37.5 & 66.5 & -29 \\
Class 5 & 75 & 99 & -24 \\
Class 6 & 91 & 175 & -84 \\
In total & 293.5 & 500.5 & -207 \\
\hline
\end{tabular}

\subsection{Text clustering analysis and abstract extraction}

The text clustering function allows NLPIR-Parser to conduct automatic hotspot analysis on a large number of text data and describe them with clustering feature words ${ }^{[14]}$. The nine clustering feature words of "classroom, attending class, topic, interesting, boring, detailed, slow, progress, pretty good" obtained from the text clustering of students' evaluation text show the students' focus on teacher's teaching methods, course characteristics, and sense of learning acquisition, such as "the discussion questions of class design are very good", "the test questions are difficult", "they can keep up with the rhythm of class" and so on.

The entity summary function allows NLPIR-Parser to automatically extract the content abstract of single or multiple articles, as well as relevant elements, so as to quickly understand the core content of corpus ${ }^{[14]}$. Students' evaluation texts are conducted with abstract and entity extraction by setting the maximum length of abstract as 300 characters, the maximum compression rate as 0 , and the number of keywords as 10 , with the results as follows:

Abstract: "It is better effect than the classes before lies in the more interaction and certain grasp of knowledge; the faster answering to our questions makes the way of screen capture have better learning effect relative to face-to-face teaching; no textbooks for us drives teachers to teach in details more slowly when taking online live classes, so that students can take notes and so on; the occasional phenomenon of laggings in the process of live broadcasting may be the network problem at my side."

The abstract reflects the positive impact of class activities on students' learning experience, the ability of teachers' teaching methods to combine the course characteristics and effectively help students improve their sense of learning acquisition, as well as the certain negative impact of network conditions on students' learning experience.

ISSN: 0010-8189 
4.4 Questionnaire score and comparative analysis

The questionnaire scores of all the classes at the level of from good to excellent have no significant difference, in which the average score of teachers' teaching is 4.64 , the average score of learning effect is 4.12 , and the total average score of the two is 4.38 (Table 6). Both the questionnaire scores and evaluation text semantic analysis significantly tend to be positive, with the consistency of taking teachers' teaching as the main source of positive evaluation and learning gains as the main source of negative evaluation, which shows the certain effectiveness of NLPIR-Parser.

According to the Pearson correlation analysis on the questionnaire score and the absolute value of sentiment analysis score of each class by SPSS 22.0, it shows that in addition to the strong correlation between teachers' teaching score and learning effect score, and a significant correlation between positive and negative scores of sentiment analysis (confidence level of 0.05), there is a certain degree of negative correlation between questionnaire score and sentiment analysis score, in which the correlation between learning effect score and negative score is significant (confidence level of 0.05) (Table 7). The reasons for the above situation need more detailed research, but it also indicates that: 1Teachers' teaching directly affects students' learning effect and experience; 2There is a high correlation between the positive and negative sentiments of students; 3The poor learning effect is closely related to the increase of negative emotion; 4Teachers' hard work has a special strengthening effect on students' positive emotion; 5) The scale design may not be reasonable enough or the text analysis may not be accurate enough, and the sample size is relatively small.

Table 6 Summary of questionnaire scores of each class

\begin{tabular}{cccc}
\hline Class & $\begin{array}{c}\text { Teachers } \\
\text { teaching }\end{array}$ & $\begin{array}{c}\text { Learning } \\
\text { effect }\end{array}$ & Total score \\
\hline Class 1 & 4.70 & 4.20 & 4.45 \\
Class 2 & 4.67 & 3.97 & 4.32 \\
Class 3 & 4.54 & 4.17 & 4.36 \\
Class 4 & 4.80 & 4.37 & 4.59 \\
Class 5 & 4.65 & 4.45 & 4.55 \\
Class 6 & 4.47 & 3.58 & 4.03 \\
Average & 4.64 & 4.12 & 4.38 \\
score & & & \\
\hline
\end{tabular}

Table 7 Pearson correlation analysis on questionnaire score and text analysis sentiment value of each class

\begin{tabular}{lllll}
\hline & $\begin{array}{l}\text { Teachers } \\
\text { teaching }\end{array}$ & $\begin{array}{l}\text { Learning } \\
\text { effect }\end{array}$ & $\begin{array}{l}\text { Positive } \\
\text { score }\end{array}$ & $\begin{array}{l}\text { Negative } \\
\text { score }\end{array}$ \\
\hline $\begin{array}{l}\text { Teachers } \\
\text { teaching }\end{array}$ & 1 & & & \\
$\begin{array}{l}\text { Learning } \\
\text { effect }\end{array}$ & 0.706 & 1 & & \\
$\begin{array}{l}\text { Positive score } \\
\text { Negative }\end{array}$ & -0.585 & -0.643 & 1 & \\
score & -0.511 & $-0.836^{*}$ & $0.915^{*}$ & 1 \\
${ }^{*}$. The correlation is significant at the confidence level (double test) of 0.05. \\
\hline
\end{tabular}

\section{Conclusions and Discussion}

The results of students' evaluation text semantic analysis and questionnaire score statistics indicate that with the overall positive learning experience, the 240 students in the six classes of online large-class teaching highly affirm teachers' teaching and learning effect, with their focus concentrated on teachers' teaching attitude, teaching

ISSN: 0010-8189

(c) CONVERTER 2020 
methods and learning gains. With $78.9 \%$ of the students participated in class feedback, the research results can reflect the learning experience of most of the research objects, which is also of positive reference significance for offline class teaching.

\subsection{Conclusions}

\subsubsection{Influencing factors of students' learning experience}

According to the above data analysis, the influencing factors of students' learning experience can be classified into 4 primary factors and 5 secondary factors (Fig. 2). Among the primary factors, teachers teaching refers to teachers' psychological tendency towards education and teaching, classroom teaching expression, teaching control and other teaching activities, including two secondary factors of teaching attitude and teaching methods; students learning refers to students' individual psychological characteristics, behaviors and intuitive feelings, such as learning motivation, class participation and grasp of teaching content, which includes three secondary factors of learning desire, classroom activities and sense of learning acquisition; curriculum characteristics refer to the basic attributes of curriculum, such as the importance, examination methods, complexity and difficulty; learning environment refers to the various software and hardware conditions and learning space characteristics affecting teachers teaching and students learning. With its direct impact on students learning, teachers teaching can also affect students' learning effect according to curriculum characteristics and learning environment, and teachers can put forward the specific suggestions to improve learning environment, thus making it play a leading role in affecting students' learning experience.

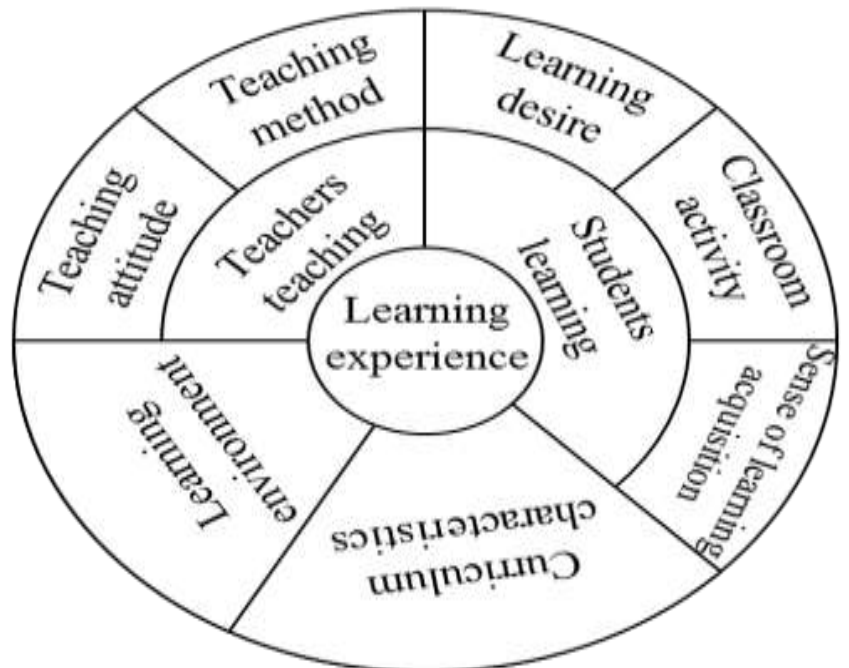

Fig 2: Influencing factors of students' learning experience in online large-class teaching

\subsubsection{Characteristics of students' learning experience and Enlightenment}

Teachers' good working attitude helps students form positive learning experience. The conclusion of teachers' teaching methods, especially teaching attitude served as the main source of students' positive learning experience is consistent with the viewpoint of Xu Lai and other scholars. Even the teaching methods to be improved cannot affect the high affirmation of students to teachers' attitude of hard work, conscientiousness and responsibility, which is beneficial to set a correct working example for students. Therefore, rectifying teaching attitude, caring students' growth, working hard on teaching preparation and classroom teaching are the important premise to improve students' learning experience.

ISSN: 0010-8189 
Improving teaching methods can effectively enhance students' learning experience. With the sense of acquisition and teaching methods served as the main source for students' negative learning experience, the difference in sentiment value score between classes 1-4 and classes 5-6 indicates that different curriculum characteristics, teaching methods and teaching objects will cause different learning experience. Teachers' teaching methods with direct effect on students' sense of learning acquisition can cover students' classroom activities, curriculum characteristics and students' learning situation. Therefore, the enhancement in pertinence, interaction, hierarchy and effectiveness of classroom teaching by improving teaching methods is an important way to improve students' sense of learning acquisition and comprehensively enhance their positive learning experience and learning effect.

Improving learning environment will optimize students' learning experience rapidly. Some of the negative experience descriptions in students' evaluation texts are caused by the poor network conditions and the disturbance to sound and image, while if this situation can be eliminated, then the corresponding evaluation vocabularies will be effectively reduced. Therefore, the improvement of learning environment, especially the software resources and hardware facilities, will quickly optimize students' learning experience.

Reducing students' negative learning experience can improve students' learning effect. There is a significantly negative correlation between the sentiment value scores of each class in text analysis and the questionnaire scores, but the overall conclusions obtained from the two research methods are consistent, which reflects the support of multi-method research for improving the reliability of research conclusion. The significantly negative correlation between the negative sentiment value scores in text analysis and the learning effect questionnaire scores indicates the reverse association between the two, that is to say, one of the effective ways to improve students' learning effect is to reduce their negative learning experience.

\subsection{Research prospect}

The main deficiency of this research is due to the lack of NLPIR-Parser deep development and application, small sample size od teachers and students, light research on interaction between text semantic analysis and questionnaire survey, the certain subjective color in the research data interpretation, the weak foundation of the same research. The semantic analysis of learning experience text as an important field in the research of education and teaching evaluation mainly includes the following research directions: Exploring more accurate methods and tools for semantic analysis of massive learning experience texts, carrying on multi-mode and multi-method comprehensive research on learning experience, constructing the correlation model of influencing factors of students' learning experience, and conducting in-depth application research on the research results of learning experience.

\section{Acknowledgements}

The Project of Basic Scientific Research Ability of Young and Middle-aged Teachers in Guangxi Universities in 2019 (2019KY1684), School-level Research Projects of Guangxi College of Education in 2017 (B2017003), one of the periodic achievements in special projects for curriculum ideological and political teaching reform in Guangxi College of Education (2020XJSZ010 and 2020XJSZ011).

\section{References}

[1] S.H. Jiang, "On the Optimization of Classroom Teaching in Large Classes of Universities," University Education Science, no. 1, pp. 27-30, 2004.

[2] Z.B. Zhang, M. Wang, B.G. Wu, G.D. Liu, "Integrated Online + Offline " Engineering Graphics Course Construction and Teaching Practice," Journal of Graphics, vol. 37, no. 5, pp. 718-725, 2016.

[3] H.N. Guan, R. Li, Y.C. Feng, "Online teaching in restructuring: action framework, implementation

ISSN: 0010-8189

(c) CONVERTER 2020

www.converter-magazine.info 
strategy and reflection," Open Education Research, vol. 27, no. 2, pp. 102-109, 2021.

[4] J.Y. Yang, W,Y. Pei, S.F. Liu, D.S. Zhang, X. Zhang, H. Jiang, L.J. Jiang, R.L. Yu, "Online Teaching Practice and Experience during Epidemic," China Educational Technology, vol. 399, no. 4, pp. 29-41, 2020.

[5] H. Li, "Emotional Analysis Model for Learners Facing Learning Experience Text," Journal of Distance Education, vol. 39, no. 1, pp. 94-103, 2021.

[6] W.J. Jia, Y.T. Guo, Z.N. Zhao, "Cluster Analysis Study on Online Learning Experience of Undergraduates," China Higher Education Research, vol. 320, no. 4, pp. 23-27, 2020.

[7] S.N.Y. Liu, X. Peng, Z. Liu, J.W. Sun, L. Liu, N.H. Zheng, "Applied Research of Learning Analysis Based on Text Mining," E-education Research, vol. 37, no. 2, pp. 23-30, 2016.

[8] W.J. Jia, Y.T. Guo, Z.N. Zhao, "Cluster Analysis Study on Online Learning Experience of Undergraduates," China Higher Education Research, vol. 320, no. 4, pp. 23-27, 2020.

[9] L. Xu, Y. Chen, Y.J. Shi, "Investigation and Analysis on Online Learning Experience of International Students in Chinese Course - A Case Study of International Students in a Domestic University," Journal of International Chinese Teaching, vol. 29, no. 1, pp. 39-49, 2021.

[10] P. Ekman, "Facial expression and emotion," American Psychologist, vol. 48, no. 4), pp. 384-392, 1993

[11] X.B. Huang, C. Zhao, "Application of Text Mining in Internet Public Opinion Information Analysis," Information Science, vol. 27, no. 1, pp. 94-99, 2009.

[12] W. Wei, Y. Xiang, Q. Chen, "Overview of Emotional Analysis of Chinese Text," Journal of Computer Applications, vol. 31, no. 12, pp. 3321-3323, 2011

[13] X.F. Xi, G.D. Zhou, "Deep Learning Research for Natural Language Processing," Acta Automatica Sinica, vol. 42, no. 10, pp. 1445-1465, 2016.

[14] H.P. Zhang, J.Y. Shang, "NLPIR-Parser: Intelligent Large Data Semantic Analysis Platform," Corpus Linguistics, PP. 87-104, 2019.

[15] S.W. Mei, H.H. Ding, "Coding/Decoding in Teaching Evaluation of University Students," Heilongjiang Education (Research and Evaluation of Higher Education), vol. 794, no. 10, pp. 82-83, 2008.

[16] Y.P. Luo, Q.X. Pan, L.N. Liu, L.H. Zhang, "Design and application of student evaluation system based on emotional mining," China Educational Technology, vol. 375, no. 4, pp. 91-95, 2018.

[17] X.J. He, X.Y. Zhu, "Empirical Research on Deep Mining of Teaching Evaluation Data of University Students," Heilongjiang Researches on Higher Education, vol. 37, no. 10, pp. 85-88, 2019.

[18] J. Wang, C.X. Wang, "Research on Influencing Factors and Improving Paths of General Education Teaching Quality in Universities Based on Analysis of Student Evaluation Texts," China Higher Education Research, vol. 324, no. 8, pp. 98-103, 2020.

[19] Y.C. Chen, W. Liu, "View Extraction and Clustering of Student Evaluation Text Based on Emotional Analysis," Journal of Computer Applications, vol. 40, no. S1, pp. 113-117, 2020.

[20] R. Cabed, T.C. Edmundo, M. Castro, "A Benchmarking Study of Clustering Techniques Applied to a Set of Characteristics of MOOC Participants//2016 ASEE Annual Conference \& Exposition: New Orleans," Louisiana, 2016.

[21] A. Ortigosa, J.M. Martin, R.M. Carrrp, "Sentiment analysis in Face-book and its application to e-learning," Computers in Human Be-havior, vol. 31, no. 2, pp. 527-541, 2014.

[22] F. Colace, M.D. Santo, L. Greco, "SAFE: A sentiment analysis frame-work for e-learning," International Journal of Emerging Technolo-gies in Learning, vol. 9, no. 6, pp. 37-41, 2014.

[23] Z.H. Tan, D.Q. Hu, Y. Tian, W. Xu, "The restructuring of interactive classroom teaching in large classes by micro-assistants,” Modern Educational Technology, vol. 28, no. 1, pp. 107-11, 2018.

ISSN: 0010-8189 